landing of C-124 at Brønlunds Fjord, North Greenland. Rep. Air Force Cambridge Research Center, $38 \mathrm{pp}$.

Troelsen, J. 1952: Notes on the Pleistocene geology of Peary Land, North Greenland. Meddr Dansk geol. Foren. 12, 211-220.

\title{
Cambrian - Early Ordovician stratigraphy in south-western Washington Land, western North Greenland
}

\author{
Niels Henriksen and John S. Peel
}

Geological reconnaissance undertaken in recent years by Dawes $(1971 ; 1975)$, and Peel \& Christie (1975) in preparation for a major mapping project in North Greenland continued in 1975 with a six week season in south-western Washington Land (fig. 5). The aim was to establish a reference profile through the lowermost Palaeozoic sequence between Cass Fjord and Humboldt Gletscher, and to obtain a preliminary idea of the possibilities for geological mapping of the platform terrain.

The Lower Palaeozoic stratigraphy of southern Washington Land has previously been studied by Koch (1929) and Troelsen (1950) who reported a sequence of dolomites and limestones of Eocambrian to Silurian age. The recognition of the Eocambrian and Cambrian deposits was based on a loose correlation with occurrences in Inglefield Land, without confirmatory fossil evidence. However, the division of Ordovician and Silurian deposits was largely proposed in Washington Land.

During our field work a composite section of the lowest $c .900 \mathrm{~m}$ of the sequence exposed in south-western Washington Land was established on the basis of 10 stratigraphical sections. The earlier results of Koch (1929) and Troelsen (1950) were partly confirmed, but in addition faunal evidence for the existence of Middle and Upper Cambrian strata was found. The Cass Fjord Formation is revised to include some of those strata and three new formations are established informally (fig. 6). Of these the Kastrup Elv and Telt Bugt formations are proposed for strata below the Cass Fjord Formation, which were only briefly noted by Koch (1929). The Christian Elv formation is proposed for strata between the Cape Clay and Poulsen Cliff Formations, the boundary between these two later formations not having been observed by Troelsen (1950).

Apart from the lowest $c .140 \mathrm{~m}$ of dolomites, the sequence is formed by various types of limestones with intercalations of dolomite, siltstone and shale, and occasional beds of sandstone and anhydrite. The sequence reflects shallow water shelf deposition; no major unconformities have been found. Fossils were collected throughout the limestone sequence and indicate deposition through the middle and late Cambrian into the early Ordovician.

The rocks were examined in two areas; one immediately north of Humboldt Gletscher, east of Benton Bugt, and the other east of the head of Cass Fjord (fig. 5). In both areas the rocks are flat lying, seldom dipping more than a few degrees. The youngest part of the section is confined to the northernmost part of the two visited areas as a result of the general 


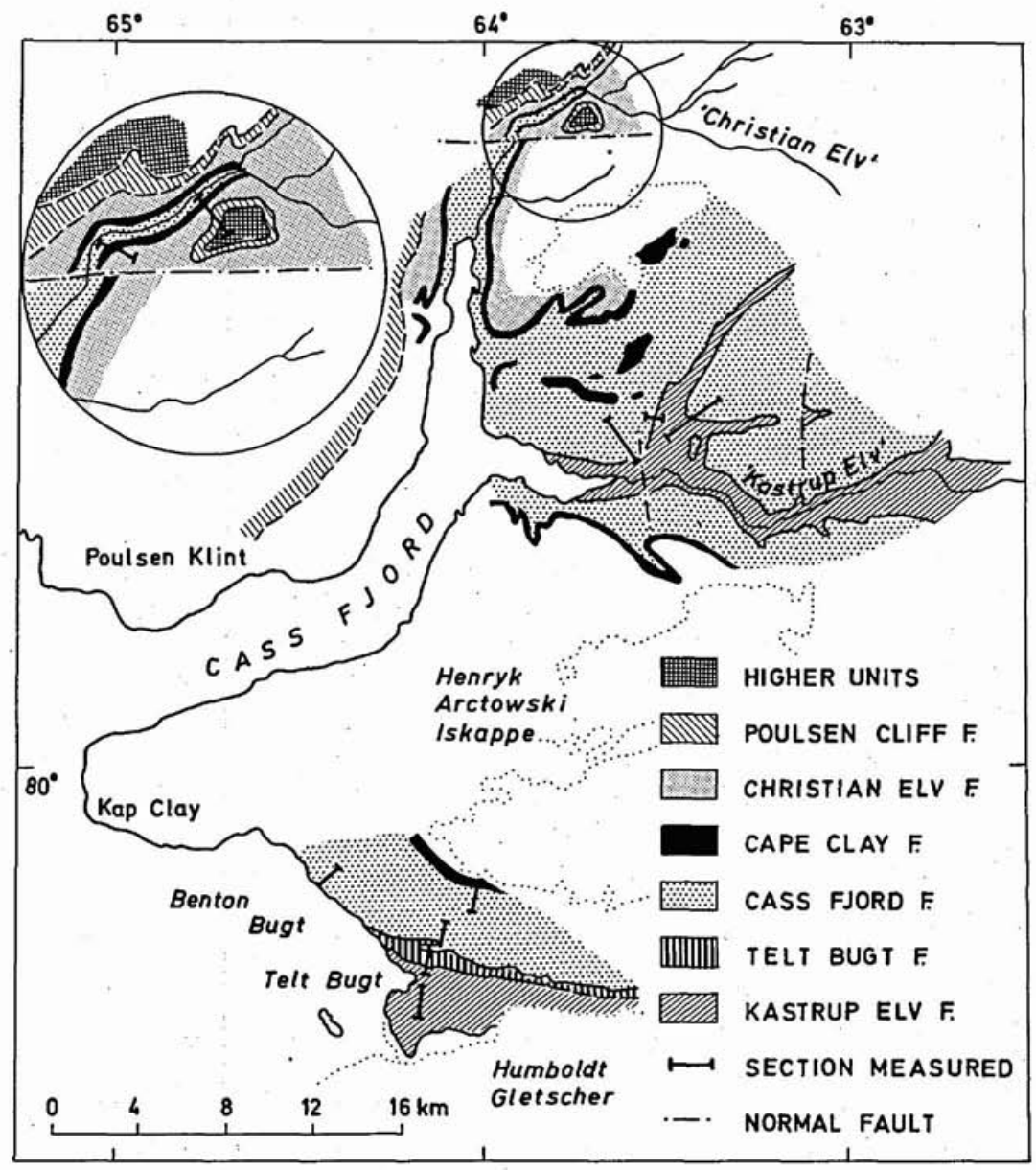

Fig. 5. Geological sketch map of part of south-west Washington Land, western North Greenland.

northerly regional dip. Local variation in the direction of dip may reflect the existence of very open undulating folding or flexuring. A limited number of near vertical normal faults was found, mainly at the head of Cass Fjord. The maximum observed displacement along one of these is $c .150 \mathrm{~m}$.

\section{Kastrup Elv formation}

The oldest exposed rocks in the area form a sequence of up to $140 \mathrm{~m}$ of yellowish, grey weathering dolomites. In the southern area north of Humboldt Gletscher only the topc. $50 \mathrm{~m}$ are exposed, but the sequence is more fully represented in the vicinity of Kastrup Elv. The rocks are therefore informally referred to as the Kastrup Elv formation. Body fossils were 


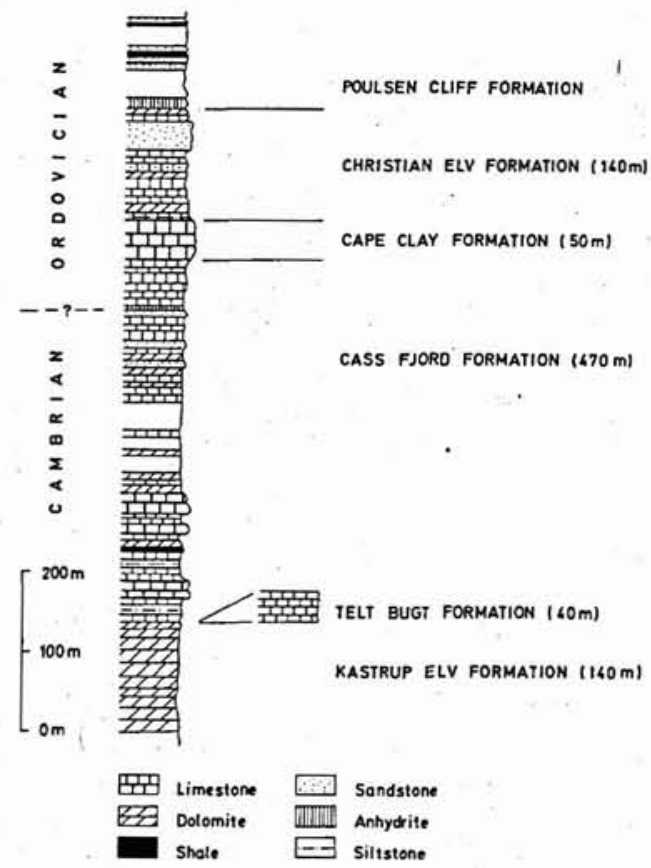

Fig. 6. Simplified geological section of Cambrian Early Ordovician rocks, south-west Washington Land, western North Greenland.

not found and therefore it has not been possible to directly establish the age of the formation. The rocks contain trace fossils at certain levels. Koch (1929) correlated the dolomites with the pre-Cambrian Thule Formation.

The formation comprises a sequence of hard, well bedded, alternating pale and dark yellowish grey dolomites. The rocks are mainly medium grained, but both fine- and more coarse-grained types occur. Crystalline and cavernous textures are conspicuous, but thin beds of dense dolomites, some well laminated, also occur. Patches and streaks of silty material are characteristic in some beds throughout nearly the whole succession producing a mottled texture. Centimetre-sized horizontal burrows occur at many levels.

The boundary with overlying fossiliferous limestone is completely gradational; $10-50 \mathrm{~cm}$ thick bands of dolomite and limestone alternate through a c. $10 \mathrm{~m}$ transition zone with the amount of limestone increasing upwards. The upper boundary of the formation is set at the highest exposure with dominantly dolomitic beds.

It is not known whether the dolomitic sequence represents a uniform stratigraphical unit or whether the dolomitisation is in part a secondary effect reaching into rocks of various stratigraphical levels. Differences in section thickness from the top of the dolomite to a reliable marker horizon in an overlying formation could be interpreted in favour of the last mentioned possibility. 


\section{Telt Bugt formation}

This c. $40 \mathrm{~m}$ succession of fossiliferous grey banded limestones has only been encountered to the north-east of Telt Bugt. The upper boundary is marked by the first appearance of intraformational conglomerate, the characteristic lithology of the Cass Fjord Formation. The Telt Bugt formation comprises thinly bedded fine-grained limestones with silty laminae and intercalations. The beds are mostly only a few centimetres thick and some bedding planes may show channelling. Dolomite infilled burrows are abundant in the limestones often giving rise to a characteristic scoriaceous weathering surface, with the burrows standing out in positive relief.

Trilobites are common with Kootenia particularly conspicuous in the lower beds. Preliminary examination of the collections suggests a Middle Cambrian age.

\section{Cass Fjord Formation}

The Cass Fjord Formation is dominated by greenish grey fine-grained limestones, characteristically with many thin beds of coarse intraformational conglomerate. The exact thickness of the formation cannot be indicated as none of the measured sections embraces the whole succession but the most complete of the composite sections east of the head of Cass Fjord indicates about $470 \mathrm{~m}$. The formation was established by Poulsen (1927) and Koch (1929) but the description was elaborated on by Troelsen (1950).

Outcrops of the formation have been investigated both to the east of Benton Bugt and at the head of Cass Fjord. The development of the succession is relatively similar in both areas and a number of characteristic mappable units occur throughout the whole area. The sequence could be subdivided into a number of members, but only the general lithological variations are described here.

The base of the formation is marked by the first appearance of intraformational conglomerate. In the Benton Bugt area the Cass Fjord Formation rests conformably on the Telt Bugt formation, but in the Cass Fjord area it follows apparently equally conformable, the dolomite-limestone alternation at the top of the Kastrup Elv formation. The lowest $c .150 \mathrm{~m}$ comprises a sequence of fine-grained, thinly bedded limestones with frequent $10-50 \mathrm{~cm}$ thick beds of intraformational conglomerate. The limestones often show silt laminae and silty partings. Mixing of lime-mud and silty components often produces a mottled texture. Channels, ripple marks, sun cracks and burrows of various types occur frequently.

Within the lowest $c$. $150 \mathrm{~m}$ two resistent units form mappable markers. These two ('lower and upper massive') units are each $20-30 \mathrm{~m}$ thick and comprise very fine-grained, thinly bedded limestones with less silty material than the adjacent parts of the sequence. Red and yellow weathering shales and dolemites between the two massive units also form a mappable marker.

The middle $c .150 \mathrm{~m}$ of the Cass Fjord Formation, often poorly exposed, contains a high proportion of fine-grained light grey and yellowish weathering platy dolomites alternating with thin limestones. A few thin anhydrite beds have been found to the east of Benton Bugt.

The highest third of the formation, mainly investigated north of Kastrup Elv, comprises fine banded limestones and dolomitic limestones with frequent silty beds. A c. $50 \mathrm{~m}$ thick unit is formed by a characteristic stripy sequence of interbanded limestones and fine-grained 
dolomitic rocks. Above follows a few sandstone horizons in the limestones with anhydrite at some levels. The upper part of the Cass Fjord Formation is very similar to the lowest part comprising fine banded limestones with silty laminae and beds of coarse intraformational conglomerate.

The upper boundary has only been examined in the Christian Elv section, where the Cass Fjord Formation is conformably overlain by rocks referred to the Cape Clay Formation. The uppermost few metres of the lower formation have a similar lithology to the Cape Clay Formation, making recognition of the exact boundary difficult without complete exposure.

Poulsen (1927) described an early Ordovician fauna with Hystricurus from the upper part of the Cass Fjord Formation. On this basis it has commonly been assumed that the entire formation is of similar age. However, preliminary examination of our fossil collections indicates that at least half of the formation should be referred to the Middle and Late Cambrian. The undescribed Late Cambrian faunas collected by geologists of the Greenarctic Consortium, recorded by Dawes (1976), seem to have been derived from near the middle of the formation. Preliminary identifications of our fossil collections by Dr. A. R. Palmer (Stony Brook, written communication, 1976) indicate the presence of strata of Dresbachian (Crepicephalus Zone) and Trempealeauian ages.

Koch's original fossil locality at Kap Clay could not be visited but Symphysurina and Hystricurus of early Ordovician (Gasconade) age were collected immediately below the top of the Cass Fjord Formation in the Christian Elv section.

\section{Cape Clay Formation}

The Cape Clay Formation is a massive recessive, yellowish grey coloured bed $c .50 \mathrm{~m}$ thick. Away from steep cliff sections weathering often produces distinctive pillars of resistant rock as noted by Koch (1929).

The formation was described by Koch (1929) from the Kap Clay area as a series of compact very hard limestones. In the Christian Elv section the formation is composed of massive yellowish brownish weathering fine- to medium-grained limestones. The sequence is only indistinctly bedded and locally small-scale reef-like structures have been observed. The rocks are hard and often finely mottled. Jointing in three directions perpendicular to each other commonly results in the formation of $10-50 \mathrm{~cm}$ long rectangular blocks.

Similar early Ordovician (Gasconade) faunas to that described by Poulsen (1927) from Kap Clay were collected in the southern area and also at Christian Elv. Symphysurina and Hystricurus are associated with frequently abundant gastropods and cephalopods. A small trilobite from the higher beds at Christian Elv resembles Pseudohystricurus rotundus described by Ross (1951) from the equivalent Zones A and B in Utah.

\section{Christian Elv formation}

In the area at the head of Cass Fjord a previously undescribed sequence $c .140 \mathrm{~m}$ thick overlies the Cape Clay Formation. These strata are informally referred to as the Christian Elv formation after their occurrence in the canyon cut by the river of that name. The sequence is dominated by fine banded grey weathering limestones with occasional beds of 
intraformational conglomerate. Silty beds and laminae occur and some limestone beds are sandy and even conglomeratic. In the middle part limestones are interbanded with dolomitic beds while in the upper part a c. $25 \mathrm{~m}$ thick well bedded, cross-bedded, sandstone occurs. The top $c .10 \mathrm{~m}$ of the formation is formed by a whitish fine banded dolomite.

Poorly preserved Ophileta were collected at several horizons. A rich fauna from near the middle of the formation includes Hystricurus, Ophileta s.s., Sinuopea and Cyrtonellopsis of early Ordovician age.

\section{Poulsen Cliff Formation}

This formation was first described by Troelsen (1950) from the area north of the entrance to Cass Fjord where the lowest part of the sequence was not exposed. The lower boundary of the Poulsen Cliff in the Christian Elv section is drawn at the first appearance of a conspicuous unit of white anhydrite with a few intercalated light grey shale beds of at least $10 \mathrm{~m}$ thickness. Fist-sized chert nodules occur in the anhydrite which forms a prominent marker band along the west side of Cass Fjord.

Above the anhydrite horizon in the Christian Elv section follows a c. $30 \mathrm{~m}$ recessive interval covered by scree. Above this are $30 \mathrm{~m}$ of shales with two horizons of thin bedded sandstones and a few thin limestone beds. Beds of intraformational conglomerate and local chert rich horizons occur occasionally.

The highest $5 \mathrm{~m}$ of rock exposed in the Christian Elv section follow a second $30 \mathrm{~m}$ covered interval. These comprise thinly laminated shales with a chert nodule level and dark grey banded limestones with intraformational conglomerates.

The division into formations of the highest $c .100 \mathrm{~m}$ of the Christian Elv section above the anhydrite is not currently practicable because of incomplete exposure. It is possible that the uppermost more resistant part should be referred to a unit above the Poulsen Cliff Formation, perhaps the $10 \mathrm{~m}$ thick Nygaard Bay Limestone of Troelsen (1950).

A limestone band in the middle of the formation contains abundant poorly preserved gastropods (Ophileta ?, Helicotoma ? and undetermined murchisoniaceans) and brachiopods, probably indicative of an early Ordovician age.

\section{References}

Dawes, P. R. 1971: The North Greenland fold belt and environs. Bull. geol. Soc. Denmark 20, 197-239.

Dawes, P. R. 1975: Reconnaissance of the Thule Group and underlying basement rocks between Inglefield Bredning and Melville Bugt, western Northern Greenland. Rapp. Grønlands geol. Unders. 75, 34-38.

Dawes, P. R. 1976: Precambrian to Tertiary of northern Greenland. In Escher, A. \& Watt, W. S. (edit.) Geology of Greenland 248-303. Copenhagen: Geol., Surv. Greenland.

Koch, L. 1929: The geology of the south coast of Washington Land. Meddr Grønland 73, I, 38 pp.

Peel, J. S. \& Christie, R. L. 1975: Lower Palaeozoic stratigraphy of southern Peary Land, eastern North Greenland. Rapp. Grønlands geol. Unders. 75, 21-25.

Poulsen, C. 1927: The Cambrian, Ozarkian and Canadian faunas of Northwest Greenland. Meddr Grønland 70, 2, 233-343. 
Ross, R. J. Jr. 1951: Stratigraphy of the Garden City Formation in Northeastern Utah, and its trilobite faunas. Bull Peabody Mus. nat. Hist. 6, 161 pp.

Troelsen, J. C. 1950: Contributions to the geology of northwest Greenland, Ellesmere Island and Axel Heiberg Island. Meddr Grønland 149, 7, 85 pp.

\title{
1:500 000 mapping of the Thule district, North-West Greenland
}

\author{
Peter R. Dawes
}

Field investigations aimed at the production of a 1:500 000 map sheet of the Thule district were continued during August and early September. The unusually poor weather conditions and the premature arrival of the winter's snowfall, reduced the season to some 20 effective working days.

The field work was in two parts. At the beginning of the season a Jet Ranger helicopter was chartered at Thule Air Base and four days were spent investigating nunatak and inland areas north of Savigsivik and Kap York and at the heads of Wolstenholme Fjord, Olrik Fjord and Inglefield Bredning. The second part was an investigation of the Proterozoic Thule Group on Herbert $\varnothing$, Northumberland $\varnothing$ and Hakluyt $\varnothing$. Transport for this phase was a locally hired boat from Avatak Henson of Moriussaq.

Certain logistic support was supplied to $H$. R. Cooke who visited the Thule district at the end of the field season to assess the economic potential of various mineral localities. Kurt Thomsen ably assisted both in Cooke's and the author's field programmes.

\section{Crystalline basement}

The main rock types and the chronological development of the Precambrian basement in the Thule district have been reported in earlier accounts (Dawes, 1972, 1975). Notes on the new mapping follow.

\section{Kap York - Savigsivik region}

In this region the Inland Ice reaches the sea as numerous wide productive glaciers restricting the ice-free areas to islands, nunataks and isolated peninsulas. De DødesFjord and Sidebriksfjord are generally inaccessible by boat. Previous reference to the geology has been restricted to mention of Archaean gneiss and granite (Chamberlin, 1895; Koch, 1920) and the meteoritic and other iron occurrences in the Savigsivik area (Peary, 1898; Bøggild, 1953).

The crystalline basement is composed of a variety of highly deformed gneisses, schists, amphibolites and supracrustal rocks, that are cut by a suite of igneous rocks (Kap York meta-igneous complex) and by still younger late Proterozoic dolerite dykes. Grey weather- 